\title{
PENGARUH KEPEMIMPINAN, DISIPLIN DAN BUDAYA ORGANISASI TERHADAP KINERJA PEGAWAI
}

\section{Adhitya Irvan Wardaka, ${ }^{\varpi}$ Hengky Pramusinto}

Jurusan Pendidikan Ekonomi, Fakultas Ekonomi, Universitas Negeri Semarang, Semarang, Indonesia

\section{Info Artikel}

Sejarah Artikel:

Diterim, 6 April 2020

Disetujui, 15 Juni 2020

Dipublikasikan, 31

Agustus 2020

\section{Keywords:}

Leadership

Discipline

Organization Culture

Employee Performance

\begin{abstract}
Abstrak
Tujuan penelitian ini untuk menganalisis adanya pengaruh Kepemimpian, Disiplin dan Budaya Organisasi terhadap Kinerja Pegawai baik secara simultan maupun parsial. Populasi dalam penelitian ini adalah 107 pegawai kelurahan se-kecamatan Sukoharjo Kabupaten Sukoharjo Jawa Tengah. Penelitian ini menggunakan teknik propotional random sampling dihitung menggunakan rumus Slovin menghasilkan responden sejumlah 84 . Metode pengumpulan data dilakukan dengan kuesioner, observasi, wawancara, dan dokumentasi. Metode analisis data menggunakan analisis deskriptif persentase dan analisis regresi. Hasil penelitian menunjukan bahwa (1) ada pengaruh yang signifikan antara kepemimpinan, disiplin, dan budaya organisasi terhadap kinerja pegawai kelurahan se-kecamatan Sukoharjo Kabupaten Sukoharjo, (2) tidak ada pengaruh yang signifikan antara kepemimpinan terhadap kinerja pegawai kelurahan se-kecamatan Sukoharjo Kabupaten Sukoharjo, (3) ada pengaruh yang signifikan antara disiplin terhadap kinerja pegawai kelurahan se-kecamatan Sukoharjo Kabupaten Sukoharjo, (4) ada pengaruh yang signifikan antara budaya organisasi terhadap kinerja pegawai kelurahan sekecamatan Sukoharjo Kabupaten Sukoharjo.
\end{abstract}

\begin{abstract}
This study was aims to analyze the influence Leadership, Discipline, and Organization Cultur to Employee Performance both simultaneously or partially. The population of this study was 107 employees in the villages in Sukoharjo Sub-district Sukoharjo regency, Central Java. This research uses proportional random sampling as technique which is calculated using Slovin formula that produces 84 respondents. The data collection method was accomplished by doing also using questionnares, observation, interviews, and documentation. This research uses data analysis method with percentage descriptive analysis and regression analysis. The results showed that (1) there is a significant influence between leadership, discipline, and organization culture on employee performance in the villages in Sukoharjo Sub-district, (2) there is no significant influence between leadership on employee performance in the villages in Sukoharjo Sub-district, (3) there is a significant influence between discipline on employee performance in the villages in Sukoharjo Sub-district, (4) there is a significant influence between organization cultur on employee performance in the villages in Sukoharjo Sub-district.
\end{abstract}

(C) 2020 Universitas Negeri Semarang

$\begin{array}{lr}\text { Alamat korespondensi: } & \text { p-ISSN 2723-4495 } \\ \text { Gedung C6 Lantai 1 FE Unnes } & \text { e-ISSN 2723-4487 } \\ \text { Kampus Sekaran, Gunungpati, Semarang, 50229 } & \end{array}$

E-mail: wardaka87@gmail.com 


\section{PENDAHULUAN}

\begin{abstract}
Manusia merupakan sumber daya utama dalam berbagai kegiatan saat menjalankan organisasi. Sumber daya manusia pada saat ini dituntut untuk melakukan perubahan supaya dapat terus berkembang dan bertahan. Menurut Notoatmojo (2003:118) penggunaan sumber daya manusia dalam organisasi adalah untuk mencapai tujuan organisasi melalui pemanfaatan dalam berbagai fungsi dan kegiatan. Oleh karena itu menurut Ambar (2003) sumber daya manusia memiliki posisi yang sangat strategis dalam organisasi, artinya unsur manusia memegang peran penting dalam melakukan aktivitas untuk pencapaian tujuan. Perubahan dapat dimulai sejak dini dan dimulai dari diri sendiri terlebih dahulu yang kemudian menjalar pada perubahan kelompok. Organisasi merupakan kesatuan sosial yang dikoordinasikan secara sadar dengan sebuah batasan yang reaktif dapat di identifikasikan, bekerja secara terus-menerus untuk mencapai tujuan (Robbins, 2006).
\end{abstract}

Organisasi swasta maupun pemerintahan tentunya memiliki sebuah tujuan, baik dalam proses jangka panjang maupun jangka pendek melalui aktivitas yang ada didalamnya. Tujuan organisasi yang telah ditetapkan dapat tercapai dengan perencanaan dan pengelolaan sumber daya manusia yang matang. Agar aktivitas manajemen berjalan dengan efektif dan efisien diperlukan pegawai dengan pengetahuan dan keterampilan kerja yang tinggi dalam mengelola organisasi secara optimal sehingga kinerja dari pegawai tersebut mengalami peningkatan. Ketika kondisi berubah lebih cepat daripada kecepatan penyesuaian budaya, kesuksesan organisasi dan bahkan kelangsungan hidup perusahaan mungkin berada dalam bahaya (Zwell, 2000).

Kinerja yang baik adalah kinerja yang optimal, yaitu kinerja yang sesuai standar organisasi dan mendukung proses tercapainya tujuan organisasi. Menurut Mangkunegara (2009:67) kinerja merupakan hasil kerja secara kualitas dan kuantitas yang dicapai oleh seorang pegawai dalam melaksanakan tugasnya sesuai dengan tanggung jawab yang diberikan kepadanya. Sedangkan menurut Ambar
(2003:223) kinerja seseorang merupakan kombinasi dari kemampuan, usaha dan kesempatan yang dapat dinilai dari hasil kerjanya. Hasibuan (2001:34) mengemukakan kinerja adalah suatu hasil kerja yang dicapai seseorang dalam melaksanakan tugas tugas yang dibebankan kepadanya yang didasarkan atas kecakapan, pengalaman dan kesungguhan serta waktu.

Kinerja merupakan suatu kondisi yang harus diketahui dan dikonfirmasikan kepada pihak tertentu untuk mengetahui tingkat pencapaian hasil suatu instansi dihubungkan dengan visi yang diemban suatu organisasi atau perusahaan serta mengetahui dampak positif dan negatif dari suatu kebijakan operasional. Kinerja adalah perilaku organisasi yang secara langsung berhubungan dengan produksi barang atau penyampaian jasa. Kinerja pegawai yang tinggi sangatlah diharapkan oleh perusahaan. Semakin banyak pegawai yang mempunyai kinerja tinggi, maka tingkat produktivitas organisasi secara keseluruhan akan meningkat. Kinerja juga berarti hasil yang dicapai oleh seseorang, baik kuantitas maupun kualitas dalam suatu organisasi sesuai dengan tanggung jawab yang dberikan kepadanya. Penilaian kinerja merupakan faktor kunci dalam mengembangkan potensi pegawai secara efektif dan efisien karena adanya kebijakan atau program yang lebih baik atas sumber daya manusia yang ada di dalam suatu organisasi.

Organisasi yang baik adalah organisasi yang berusaha meningkatkan kemampuan sumber daya manusianya, karena hal tersebut merupakan kunci utama untuk meningkatkan kinerja pegawai. Oleh karena itu dalam meningkatkan kinerja pegawai merupakan sebuah tantangan yang harus diselesaikan oleh organisasi dan digerakkan oleh pemimpinnya. Pegawai dalam bekerja dituntut untuk mampu menyelesaikan tugas dan tanggung jawabnya secara efektif dan efisien. Menurut Ardila dan Pramusinto (2015) bahwa kinerja seseorang sangat diperlukan, sebab dengan kinerja ini dapat diketahui seberapa jauh kemampuan seseorang dalam melaksanakan tugasnya. Terdapat faktor negatif yang dapat menurunkan 
kinerja pegawai, diantaranya adalah menurunnya keinginan pegawai untuk mencapai prestasi kerja, kurangnya ketepatan waktu dalam penyelesaian pekerjaan sehingga kurang menaati peraturan, pengaruh yang berasal dari lingkungannya, teman sekerja yang juga menurun semangatnya dan tidak adanya contoh yang harus dijadikan acuan dalam pencapaian prestasi kerja yang baik.

Pegawai Negeri Sipil merupakan pegawai pemerintah dengan perjanjian kerja yang diangkat oleh pejabat Pembina kepegawaian dan diserahi tugas dalam suatu jabatan pemerintahan atau diserahi tugas Negara lainnya dan digaji berdasarkan peraturan perundang-undangan. Oleh karena itu, seorang ASN harus memiliki kinerja yang telah distandarkan.

Kinerja pegawai negeri sipil merupakan salah satu ukuran yang menyatakan seberapa jauh target (kuantitas, kualitas, dan waktu) yang telah dicapai oleh pegawai negeri sipil, dimana target tersebut telah ditetapkan terlebih dahulu sesuai dengan ketentuan dan wewenangnya dalam pemerintahan. Maka dari itu kinerja pegawai harus ditingkatkan sesuai dengan Peraturan Pemerintah Nomor 32 Tahun 2004 tentang Pemerintahan Daerah bahwa pemberian otonomi kepada daerah dimaksudkan untuk meningkatkan daya guna dan hasil guna penyelenggaraan pemerintah di daerah, terutama dalam pelaksanaan pembangunan dan pelayanan terhadap masyarakat serta untuk meningkatkan pembinaan kestabilan politik dan kesatuan bangsa.

Pada organisasi, kepemimpinan adalah suatu proses ketika seseorang berperan sebagai pemimpin dan berjalan secara terus menerus sesuai dengan periode yang telah ditentukan sehingga dapat mempengaruhi bawahannya untuk mencapai sebuah tujuan organisasi. Temuan Potu (2013) bahwa kepemimpinan secara parsial berpengaruh positif dan signifikan terhadap kinerja karyawan pada Kantor Wilayah Ditjen Kekayaan Negara Suluttenggo dan Maluku Utara di Manado. Hal senada dari temuan Antou (2013) bahwa gaya kepemimpinan secara parsial berpengaruh positif dan signifikan terhadap kinerja pegawai kantor kelurahan Malalayang I Manado. Hasil ini didukung dengan penelitian Ato'Illah (2004:15) bahwa gaya kepemimpinan berpengaruh dominan dan signifikan terhadap kinerja pegawai kelurahan di kecamatan Lumajang kabupaten Lumajang. Sedangkan penelitian dari Ardila \& Pramusinto (2015) menyimpulkan bahwa variabel kepemimpinan secara parsial berpengaruh signifikan dan positif terhadap kinerja pegawai BP3MD provinsi Sumatra Selatan.

Pimpinan merupakan panutan untuk para pegawainya, maka dalam memimpin suatu organisasi hendaklah bercitra yang positif dihadapan seluruh pegawai. Citra positif tidak hanya diberlakukan di organisasi saja tetapi dilingkungan luar organisasi citra tersebut tetap harus ditanamkan oleh seorang pemimpin. Menurut Ningsih dan Pramusinto (2017) bahwa citra adalah gambaran atas perilaku di mata orang lain dan masyarakat tentang kelompok, perusahaan atau instansi, selain itu citra merupakan kesan yang diterima oleh seseorang berdasarkan pengetahuan dan pengertian tentang fakta-fakta yang didapat melalui informasi.

Dalam pengoptimalan tugas atau kinerja pegawai maka diperlukan kepemimpinan berjiwa tinggi yang bisa mengatur, memotivasi, mengawasi dan menggerakkan pegawai dengan baik agar tujuan yang ingin dicapai dapat terlaksana dengan efektif dan efisien. Kepemimpinan merupakan masalah utama di organisasi, jika kepemimpinan dijalankan sesuai keinginan pemimpin itu sendiri tanpa memperhatikan kritik dan saran bawahannya maka dapat dikatakan pemimpin itu kurang berhasil dalam menjalankan tugasnya. Ketika terjadi hal semacam itu maka kinerja pegawai akan menurun dan organisasi tersebut dapat dikatakan gagal karena tidak ada keharmonisan antar pimpinan dan pegawai.

Setiap pemimpin organisasi tentu memiliki ciri khas masing-masing atau biasa dikatakan dengan gaya kepemimpinan yang dijalankan berbeda-beda, maka dari itu seorang pemimpin harus bisa memaksimalkan gaya kepemimpinannya di organisasi dengan memperhatikan sifat dan keadaaan para pegawainya. Gaya kepemimpinan merupakan norma perilaku yang digunakan oleh seseorang 
pada saat orang tersebut mencoba mempengaruhi perilaku orang lain (Suranta, 2002).

Ketika memimpin organisasi sebaiknya memberikan contoh yang baik kepada para pegawai seperti meningkatkan kedisiplinan kerja, baik itu dilihat dari berangkat dan pulang kerja maupun penyelesaian tugas atau target tugas yang akan diselesaikan. Handoko (2000: 134) menyatakan bahwa tidak ada satupun gaya kepemimpinan yang terbaik yang berlaku universal untuk segala situasi dan lingkungan, maka pendekatan situasional atau kontingensi dalam memilih model kepemimpinan yang efektif menjadi alternatif jawaban terbaik. Amrulloh dan Hengky (2017) memberikan saran bahwa pimpinan diharapkan dapat memberikan gagasan maupun contoh dalam menyelesaikan pekerjaan dengan cara misalnya melalui pembagian kerja yang efektif kepada perangkat desa.

Suatu organisasi yang baik selalu mempunyai aturan internal dalam rangka meningkatkan kinerja dan profesionalisme, budaya organisasi maupun kebersamaan, kehormatan, dan kredibilitas organisasi serta untuk menjamin tetap terpeliharanya tata tertib organisasi dalam pelaksanaaan tugas sesuai tujuan, peran, fungsi, wewenang dan tanggung jawab institusi tersebut. Bagi yang melanggar aturan yang telah ditentukan maka pemimpin dapat diberikan peringatan terlebih dahulu. Organisasi yang berjalan optimal tidak dapat dikaitkan sepenuhnya hanya pada kebutuhan ekonomi saja, karena pada kenyataannya faktor disiplin kerja mempunyai peranan yang tidak kalah penting untuk membentuk seseorang mempunyai tanggung jawab dalam bekerja. Kemampuan yang dimiliki pegawai yaitu pengetahuan dan keterampilan yang diharapkan mengetahui, memahami, melaksanakan, dan mematuhi segala aturan dan norma yang berlaku dalam lingkungan kerja sebagai sistem organisasi yang akhirnya dapat memenuhi tujuan yang ditetapkan oleh organisasi itu sendiri.

Hasibuan (2004) berpendapat bahwa kedisiplinan adalah kesadaran dankesediaan seseorang menaati semua peraturan perusahaan dan norma-norma sosial yang berlaku.
Sedangkan temuan Hidayat dan Taufiq (2012:94) bahwa disiplin kerja berpengaruh dominan terhadap kinerja karyawan PDAM Lumajang. Temuan Arofah \& Pramusinto (2015) menemukan bahwa secara parsial ada pengaruh antara disiplin kerja terhadap kinerja perangkat desa di kecamatan Tulis kabupaten Batang.

Budaya organisasi merupakan kumpulan kepercayaan, harapan, dan nilai-nilai yang dianut bersama oleh anggota organisasi dan diwariskan dari satu generasi ke generasi berikutnya. Menurut Koesmono (2005:167) budaya organisasi adalah perekat sosial yang mengingat anggota dari organisasi. Agar suatu karakteristik atau kepribadian yang berbedabeda antara orang yang satu dengan orang yang lain dapat di satukan dalam suatu kekuatan organisasi maka perlu adanya perekat sosial. Saputri dan Muhsin (2018) menyatakan bahwa budaya organisasi merupakan nilai, sikap, asumsi, dan norma perilaku yang hidup dalam suatu organisasi yang membentuk penampilan, sikap, dan tindakan, sehingga menjadi identitas dari organisasi tertentu.

Maabuat (2016:230) menemukan bahwa tidak ada pengaruh antara budaya organisasi dengan kinerja pegawai Dispenda Sulut UPTD Tondano. Temuan Antou (2013:158) bahwa budaya organisasi berpengaruh positif terhadap kinerja pegawai di kantor Kelurahan Malalayang Manado. Pegawai yang tidak mau merubah pola pikir budaya organisasi yaitu tetap memakai mesin ketik dibandingkan dengan komputer pastinya akan menghambat dari tujuan organisasi tersebut. Oleh karena itu, seorang pemimpin harus bisa memaksimalkan budaya organisasi dalam organisasi dimana kegiatan yang perlu ditinggalkan dan mana yang harus diperbarui. Budaya organisasi tidak hanya dilihat dari peralatan kantor tetapi juga dari tata cara berbicara dengan atasan dan pegawai lain harus sesuai dengan etika dan norma-norma yang berlaku.

Dalam meningkatkan kinerja pegawai perlu mengamati tentang budaya yang ada disuatu organisasi, jika budaya di organisasi kurang baik semisal kurangnya tingkat komunikasi antar pegawai yang diturunkan tiap periode maka kinerja yang terjadi di organisasi 
tersebut dapat dikatakan kurang produktif dalam menyelesaikan tugas atau pekerjaannya.

Tujuan dari penelitian ini adalah untuk menganalisis pengaruh antara kepemimpinan, disiplin dan budaya organisasi terhadap kinerja pegawai kelurahan se-kecamatan Sukoharjo Kabupaten Sukoharjo Jawa Tengah.

\section{METODE PENELITIAN}

Penelitian ini termasuk penelitian kuantitatif. Populasi dalam penelitian ini adalah 107 pegawai kelurahan se-kecamatan Sukoharjo Kabupaten Sukoharjo Jawa Tengah. Penelitian ini menggunakan teknik propotional random sampling dihitung menggunakan rumus Slovin menghasilkan responden sejumlah 84 . Metode pengumpulan data dilakukan dengan kuesioner, observasi, wawancara, dan dokumentasi. Metode analisis data menggunakan analisis deskriptif persentase dan analisis regresi.

\section{HASIL DAN PEMBAHASAN}

Berdasarkan hasil uji hipotesis yang telah dilakukan diketahui bahwa uji simultan (F) menunjukkan hasil nilai signifikansi sebesar $0,000<0,05$ maka $\mathrm{Ha}_{1}$ yang menyatakan terdapat pengaruh kepemimpinan, disiplin dan budaya organisasi terhadap kinerja pegawai kelurahan se-kecamatan Sukoharjo kabupaten Sukoharjo, diterima. Sedangkan berdasarkan hasil uji parsial (t) menunjukkan nilai signifikansi variabel kepemimpinan sebesar 0,530, disiplin sebesar 0,032, dan budaya organisasi sebesar 0,000. Dari hasil tersebut maka hipotesis kepemimpinan memiliki pengaruh positif tetapi tidak signifikan terhadap kinerja pegawai, sedangkan disiplin dan budaya organisasi memiliki pengaruh positif dan signifikan terhadap kinerja pegawai kelurahan se kecamatan Sukoharjo Kabupaten Sukoharjo

$\begin{aligned} & \text { Koefisien determinasi simultan }\left(\mathrm{R}^{2}\right) \\ & \text { adalah untuk mengukur seberapa jauh }\end{aligned}$ kemampuan model dalam menerangkan variasi variabel dependen. Nilai koefisien determinasi adalah antara nol dan satu. Koefisien determinasi simultan bertujuan untuk mengetahui besarnya hubungan atau kepemimpinan, disiplin, dan budaya organisasi terhadap kinerja pegawai. Koefisien determinasi simultan $\left(\mathrm{R}^{2}\right)$ diketahui dari nilai Adjusted $\mathrm{R}$ Square adalah 0,481; hal ini berarti 48,1\% variasi kinerja pegawai dapat dijelaskan oleh variasi dari ke tiga variabel independen yaitu kepemimpinan, disiplin dan budaya organisasi. Sedangkan sisanya $(100 \%-48,1 \%=51,9 \%)$ dijelaskan oleh sebab-sebab variabel lain yang tidak ada dalam penelitian ini.

Koefisien determinasi parsial $\left(\mathrm{r}^{2}\right)$ diketahui besarnya kontribusi variabel kepemimpinan terhadap kinerja pegawai sebesar $(0,070)^{2} \times 100 \%=0,49 \%$. Kontribusi variabel disiplin terhadap kinerja pegawai sebesar $(0,237)^{2} \times 100 \%=5,61 \%$. Selanjutnya kontribusi variabel budaya organisasi terhadap kinerja pegawai sebesar $(0,423)^{2} \times 100 \%=17,8$. Analisis regresi berganda digunakan untuk mengetahui bentuk pengaruh kepemimpinan, disiplin dan budaya organisasi terhadap kinerja pegawai kelurahan se-kecamatan Sukoharjo Kabupaten Sukoharjo secara simultan, untuk menguji secara parsial variabel-variabel bebas tersebut berpengaruh dan untuk mengetahui besarnya koefisien determinasi baik secara simultan maupun parsial. Hasil analisis regresi berganda dengan menggunakan bantuan IBM SPSS 21.0 for Windows diperoleh hasil sebagai berikut.

Tabel 1. Hasil Uji Regresi Berganda

\begin{tabular}{llccccc}
\hline \multirow{2}{*}{ Model } & \multicolumn{2}{c}{$\begin{array}{c}\text { Unstandardized } \\
\text { Coefficients }\end{array}$} & $\begin{array}{c}\text { Standardized } \\
\text { Coefficients }\end{array}$ & \multirow{2}{*}{ T } & \multirow{2}{*}{ Sig. } \\
\cline { 3 - 5 } & \multicolumn{1}{c}{ B } & Std. Error & Beta & & \\
\hline \multirow{2}{*}{1} & (Constant) & 9,334 & 3,163 & & 2,952 & 0,004 \\
\cline { 3 - 5 } & Kepemimpinan & 0,520 & 0,082 & 0,071 & 0,631 & 0,530 \\
\hline
\end{tabular}




\begin{tabular}{lrrrrr} 
Disiplin & 0,278 & 0,128 & 0,251 & 2,177 & 0,032 \\
Budaya Organisasi & 0,380 & 0,091 & 0,464 & 4,175 & 0,000 \\
\hline
\end{tabular}

Sumber: Data penelitian diolah

Hasil analisis regresi berganda tersebut diolah menggunakan bantuan IBM SPSS 21.0 for windows, menghasilkan persamaan $\mathrm{Y}=9,334+$ $0,052 \mathrm{X} 1+0,278 \mathrm{X} 2+0,380 \mathrm{X} 3+$ e. Nilai konstan kinerja pegawai pada persamaan regresi sebesar 9,334. Hal ini berarti sebelum adanya pengaruh dari kepemimpinan, disiplin dan budaya organisasi terhadap kinerja pegawai sebesar 9,334. Koefisien regresi linier berganda variabel kepemimpinan bernilai positif sebesar 0,052 artinya apabila variabel independen lain nilainya tetap dan kepemimpinan mengalami kenaikan satu satuan maka kinerja pegawai akan mengalami kenaikan sebesar 0,052. Koefisien regresi linier berganda disiplin sebesar 0,278 bertanda positif. Artinya apabila variabel independen lain nilainya tetap dan disiplin kerja mengalami kenaikan satu satuan maka kinerja pegawai akan mengalami kenaikan sebesar 0,278 . Koefisien regresi linier berganda budaya organisasi sebesar 0,380 bertanda positif. Artinya apabila variabel independen lain nilainya tetap dan budaya organisasi mengalami kenaikan satu satuan maka kinerja pegawai akan mengalami kenaikan sebesar 0,278.

Berdasarkan uji simultan menunjukkan hasil perolehan Fhitung sebesar 26,629 dan sig = $0,000<5 \%$ yang artinya bahwa terdapat pengaruh positif dan signifikan antara kepemimpinan, disiplin dan budaya organisasi terhadap kinerja pegawai kelurahan sekecamatan Sukoharjo kabupaten Sukoharjo.

Berdasarkan hasil perhitungan yang telah dilakukan diperoleh hasil dari koefisien determinasi simultan sebesar $48,1 \%$ artinya kepemimpinan, disiplin dan budaya organisasi memberikan pengaruh sebesar $48,1 \%$ terhadap kinerja pegawai kelurahan se-kecamatan Sukoharjo Kabupaten Sukoharjo dan sisanya dipengaruhi oleh variabel lain baik yang ada dalam penelitian ini maupun tidak.

Hasil perhitungan menunjukkan thitung sebesar 0,631 dengan signifikansi 0,530 >0,05. Hal ini berarti hipotesis $2\left(\mathrm{H}_{2}\right)$ yang berbunyi bahwa "terdapat pengaruh positif tetapi tidak signifikan antara kepemimpinan terhadap kinerja pegawai kelurahan se-kecamatan Sukoharjo kabupaten Sukoharjo" dinyatakan ditolak. Penolakan terhadap hipotesis $\mathrm{H}_{2}$ mengidentifikasi bahwa tinggi rendahnya kepemimpinan tidak berpengaruh terhadap tinggi rendanya kinerja pegawai. Hal tersebut sesuai dengan penelitian yang dilakukan oleh Potu (2013) bahwa kepemimpinan secara parsial bepengaruh positif dan signifikan terhadap kinerja karyawan pada Kantor Wilayah Ditjen Kekayaan Negara Suluttenggo Dan Maluku Utara Di Manado.

Hasil perhitungan menunjukkan thitung sebesar 2,177 dengan signifikansi $0,032<0,05$. Hal ini berarti hipotesis $3\left(\mathrm{H}_{3}\right)$ yang berbunyi bahwa "terdapat pengaruh positif dan signifikan disiplin terhadap kinerja pegawai kelurahan sekecamatan Sukoharjo kabupaten Sukoharjo" dinyatakan diterima. Penerimaan $\mathrm{H}_{3}$ mengindikasikan bahwa semakin tinggi disiplin yang dimiliki oleh pegawai, maka kinerja pegawai juga akan semakin meningkat. Begitupun sebaliknya, apabila disiplin rendah, maka kinerja pegawai otomatis akan semakin menurun. Hal tersebut sejalan dengan penelitian yang dilakukan oleh Harlie (2011), membuktikan bahwa disiplin kerja $\left(\mathrm{X}_{1}\right)$, motivasi $\left(\mathrm{X}_{2}\right)$, dan pengembangan karier $\left(\mathrm{X}_{3}\right)$ berpengaruh nyata secara parsial terhadap kinerja pegawai (Y). Variabel disiplin kerja merupakan variabel bebas yang dominan mempengaruhi variabel terikat yaitu kinerja pegawai $(\mathrm{Y})$.

Hasil perhitungan menunjukkan $t_{\text {hitung }}$ sebesar 4,175 dengan signifikansi 0,000 >0,05. $\mathrm{Hal}$ ini berarti hipotesis $4\left(\mathrm{H}_{4}\right)$ yang berbunyi bahwa "terdapat pengaruh positif dan signifikan antara budaya organisasi terhadap kinerja pegawai kelurahan se-kecamatan Sukoharjo Kabupaten Sukoharjo" dinyatakan diterima. Penerimaan $\mathrm{H}_{4}$ mengindikasikan bahwa semakin tinggi budaya organisasi yang dimiliki oleh pegawai, maka kinerja pegawai juga akan semakin meningkat. Begitupun sebaliknya, 
apabila budaya organisasi rendah, maka kinerja pegawai otomatis akan semakin menurun. Hal tersebut temuan Suryani dan Budiono (2016) bahwa budaya organisasi mempengaruhi secara langsung terhadap kinerja karyawan pada PT. Kerta Rajasa Raya. Sedangkan Temuan Antou (2013) menunjukan bahwa budaya organisasi secara parsial berpengaruh positif dan signifikan terhadap kinerja pegawai kantor kelurahan Malalayang I Manado.

\section{SIMPULAN}

Berdasarkan hasil penelitian dan pembahasan maka diperoleh kesimpulan yaitu 1) Ada pengaruh yang signifikan antara kepemimpinan, disiplin, dan budaya organisasi terhadap kinerja pegawai kelurahan sekecamatan Sukoharjo Kabupaten Sukoharjo provinsi Jawa Tengah; 2) Tidak ada pengaruh yang signifikan antara kepemimpinan terhadap kinerja pegawai kelurahan se-kecamatan Sukoharjo Kabupaten Sukoharjo provinsi Jawa Tengah; 3) Ada pengaruh yang signifikan antara disiplin terhadap kinerja pegawai kelurahan sekecamatan Sukoharjo Kabupaten Sukoharjo provinsi Jawa Tengah; 4) Ada pengaruh yang signifikan antara budaya organisasi terhadap kinerja pegawai kelurahan se-kecamatan Sukoharjo Kabupaten Sukoharjo provinsi Jawa Tengah.

\section{DAFTAR PUSTAKA}

Ambar T. (2003). Manajemen Sumber Daya Manusia, Konsep Teori dan Pengembangan dalam Konteks Organisasi Publik. Edisi Pertama. Yogyakarta: Graha Ilmu.

Amrulloh, A. M. K., dan Hengky Pramusinto. (2017). Pengaruh Kepemimpinan Kepala Desa, Fasilitas Kantor, dan Kompensasi Terhadap Kinerja SeKecamatan Sukorejo. Economic Education Analysis Journal, 6 (3), 912922. Semarang: Universitas Negeri Semarang

Antou, Doni Oktavianus. (2013). Gaya Kepemimpinan dan Budaya
Organisasi Pengaruhnya terhadap Kinerja Pegawai Kantor Kelurahan Malalayang I Manado. Jurnal EMBA Vol.1 No.4 2013, Hal. 151-159. Manado: Universitas Sam Ratulangi.

Ardila, N., \& Pramusinto, H. (2015). Pengaruh Kepemimpinan, Komunikasi Internal Dan Motivasi Kerja Terhadap Kinerja Pegawai Bpakb Provinsi Jawa Tengah. Dinamika Pendidikan, 10(1), 53-66.

Arofah, Rupik dan Hengky Pramusinto. (2015). Pengaruh Fasilitas Kantor, Motivasi Kerja dan Disiplin Kerja Terhadap Kinerja Perangkat Desa di Kecamatan Tulis Kabupaten Batang. Dalam Jurnal Pendidikan Ekonomi. Semarang Universitas Negeri Semarang.

Ato'Illah, Mohammad. (2014). Analisis Pengaruh Gaya Kepemimpinan dan Motivasi terhadap Kinerja Pegawai Kelurahan Di Kecamatan Lumajang Kabupaten Lumajang. Jurnal WIGA Vol. 4 No. 1, ISSN NO 2088-0944. Lumajang: STIE Widya Gama Lumajang.

Harlie, M. (2012). Pengaruh Disiplin Kerja, Motivasi dan Pengembangan Karier terhadap Kinerja Pegawai Negeri Sipil pada Pemerintah Kabupaten Tabalong di Tanjung Kalimantan Selatan. ISSN: 1693-5241. Tabalong: STIA Tabalong Kalimantan Selatan.

Hasibuan, Malayu. (2002). Manajemen Sumber Daya Manusia. Edisi Revisi. Bandung: Penerbit Bumi Askara.

Handoko, T. Hani. (2000). Manajemen. Edisi 2. Yogyakarta: BPFE

Hidayat, Zainul MM \& Muchamad Taufiq, MH. (2012). Pengaruh Lingkungan Kerja dan Disiplin Kerja serta Motivasi Kerja terhadap Kinerja 
Karyawan Perusahaan Daerah Air Minum (PDAM) Kabupaten Lumajang. Jurnal WIGA Vol. 2 No. 1, ISSN NO 2088-0944. Lumajang: STIE Widya Gama Lumajang.

Koesmono, H.Teman. (2005). Pengaruh Budaya Organisasi Terhadap Motivasi Dan Kepuasan Kerja Serta Kinerja Karyawan Pada Sub Sektor Industri Pengolahan Kayu Skala Menengah Di Jawa Timur. Jurnal Manajemen \& Kewirausahaan, Vol. 7, No. 2, September. 162-179

Maabuat, Edward S. (2016). Pengaruh Kepemimpinan, Orientasi Kerja, Dan Budaya Organisasi Terhadap Kinerja Pegawai (Studi Pada Dispenda Sulut Uptd Tondano). Jurnal Berkala Ilmiah Efisiensi Volume 16 No. 01. Manado: Universitas Sam Ratulangi.

Mangkunegara, Anwar Prabu. (2009). Manajemen Sumber Daya Manusia Perusahaan. Bandung: PT. Remaja Rosda Karya.

Ningsih, Israyati Tresna dan Hengky Pramusinto. (2017). "Peran Humas Dalam Meningkatkan Citra Sekolah Di SMK Sempiuh Kab. Banyumas". Economic Education Analysis Journal. Universitas Negeri Semarang. EEAJ6 (2) 2017

Notoadmodjo, Soekidjo. (2003). Pengembangan Sumber Daya Manusia. Jakarta: Rineka Cipta.

Peraturan Pemerintah Nomor 32 Tahun 2004 tentang Pemerintahan Daerah.

Potu, Aurelia. (2013). Kepemimpinan, Motivasi, dan Lingkungan Kerja Pengaruhnya terhadap Kinerja Karyawan pada Kanwil Ditjen Kekayaan Negara Suluttenggo dan Maluku Utara Di Manado. Jurnal EMBA Vol.1 No.4, Hal. 1208-1218. Manado: Universitas Sam Ratulangi.
Robbins, Stephen P. (2006). Perilaku organisasi. Edisi Bahasa Indonesia. Jakarta: PT Indeks Kelompok GRAMEDIA.

Saputri, Eka Dewi dan Muhsin. (2018). Peran Komitmen Organisasi dalam Memediasi Pengaruh Variabel Keteladanan Pemimpin, Kompetensi Perangkat Desa, dan Budaya Organisasi Terhadap Kinerja. Economic Education Analysis Journal. Semarang: Universitas Negeri Semarang

Suranta, Sri. (2002). Dampak Motivasi Karyawan Pada Hubungan Antara Gaya Kepemimpinan Dengan Kinerja Karyawan Perusahaan Bisnis. Empirika.Vol 15. No 2. Hal: 116-138.

Suryani, Dewi dan Budiono. (2014). Pengaruh Budaya Organisasi Terhadap Kinerja Karyawan melalui Komitmen Organisasi sebagai Variabel Intervening pada PT Kerta Rajasa Raya. Journal of Research in Economics and Management. Vol. 16, No. 1, Hal 29-43. Surabaya: Universitas Negeri Surabaya.

Zwell, M. (2000). Creating a Culture of Competence. Canada: John Wiley \& Sons, Inc. 